\title{
Empowering Your Students Satisfaction with Blended Learning: A Lesson from the Arabian Gulf University Distance Teaching and Training Program
}

\author{
Alajab Mohammed Alajab Ismail
}

\begin{abstract}
Learning and instruction effectiveness repent main issues in the educational process; blended learning nowadays has become a major educational approach during the last decades as enrollment in online courses continues to increase. Therefore, there is an increasing need to understand factors that affect the students' satisfaction with the blended learning experience and its impact on post-graduate programs learning outcomes. This research explores an enhanced blended learning approach for teaching a graduate learning theory course at the Arabian Gulf University and assesses its impacts on subjects' satisfaction with the blended learning experience. Twenty tow $(n=22)$ diploma and master students, between the ages of 25-38 years old, were participated in the present study and taught the learning theory course (DE 05013) by using the proposed enhanced blended learning approach: intensive face-to-face sessions, online learning, free internet search, small class discussions and online discussions using WatsApp. A satisfaction with blended learning instrument was administrated by the end of the course for the data collection. Satisfaction with blended learning instruments was composed of three parts (satisfaction with the subject matter, satisfaction with the teaching method and satisfaction with the course instructor).Data analysis revealed that students' satisfaction could increase when the instructor provides learning environments not only in a traditional classroom but in an asynchronous online system as well.
\end{abstract}

Index Terms - Blended learning, open and distance learning, satisfaction with learning, distance teaching and training program.

\section{INTRODUCTION}

The current literature sees blended learning as a combination of face-to-face and technology-mediated instructional forms and practice. Blended learning has been regarded as a new paradigm in modern education that convergences e-learning and (face to face) learning. Blended learning is part of the ongoing convergence of two representative learning environments. On the one hand, there is a traditional $\mathrm{f} 2 \mathrm{f}$ learning environment that has been around for centuries, on the other hand, there were distributed learning environments that have begun to grow and expand in exponential ways as new information and communication technologies have expanded the possibilities for distributed communication and interactions [1]. The degree of learners'

Manuscript received March 8, 2017; revised May 23, 2017. This work was funded by the Arabian Gulf University, College of Graduate Studies.

Alajab Mohammed Alajab Ismail is with the Department of Distance Learning, College of Graduate Studies, Arabian Gulf University. Manama, B.O.Box:26671, Kingdom of Bahrain (e-mail: alagabm@agu.edu.bh). satisfaction with blended learning plays a crucial role in evaluating the effectiveness of blended learning adoption. Authors [2] examined the primary factors affecting learners' satisfaction in the blended learning environment. They used a comprehensive questionnaire to assess the impact of six dimensions such as learner, instructor, course, technology, design, and environment, on perceived e-learner satisfaction specifically on the e-learning component within the blended learning environment. The respondents for their study were generally young with an average age of 20 years old. Results from univariate regression analysis revealed all six dimensions to be positively associated with perceived e-learner satisfaction. Their study concluded that younger generation prioritized the design dimension to be the most critical factor in their satisfaction towards e-learning components in the blended learning environment. Therefore, it may be more strategic for institutions to emphasize on the design dimension in their e-learning implementations within the blended learning environment specifically for younger learners.

With the arrival of the computer and the Internet, many higher institutions in Malaysia have begun to integrate conventional teaching with these two technologies. This approach in learning which is also called "blended learning" offers significant benefits, namely time and location shifting. However, the principles applied to activities designed as a blended course must be taken into consideration especially when the students are off campus adult learners with minimal opportunity to attend conventional tutorials. To improve course quality [3] conducted a study to look into this issue by seeking feedback from adult learners regarding blended learning within an academic reading course at a Malaysian public university, National University of Malaysia (UKM). The method of inquiry of this study is qualitative in nature and which utilizes observation, Think-aloud Protocol and semi-structured interviews as the research instruments. The subjects of this study were selected from off-campus students who were attached to various hospitals. The focus of this paper is to discuss the students' feedback pertaining to the designed hypermedia and comprehension questions. The study also explains some pedagogic implications. The implications drawn is of great value to the students; teachers as the facilitators; teachers as the course designers and the administrators in improving blended learning course offered to UKM off campus students.

Authors [4] explored the application of the principles of adult learning in the face to face (f2f) meetings organized within the context of blended learning courses. The study 
adopts a case study approach, employing qualitative data collection through semi-structured interviews with participants in four thematic units in two distance learning program: Greek Civilization (undergraduate) and Education Studies (graduate) organized by the Open University of Cyprus and the Hellenic Open University. The research draws on andragogy and illustrates the experiences and perceptions of 16 adult learners and eight tutors with regard to the design of the $\mathrm{f} 2 \mathrm{f}$ meetings, the educational techniques and means used the participation, and the perceived usefulness of such sessions. The article concludes by highlighting the limited use of the adult learning principles in designing and implementing f2f meetings during the distance learning programs explored. Recommendations for the design of $\mathrm{f} 2 \mathrm{f}$ sessions in consideration of adult learning are made.

In 2013, [5] investigated the need for developing a blended learning strategy based on a major review of the surveying course, including analysis of its content, benchmarking with key national and international universities, and surveys of key stakeholders. Appropriate blended learning methods and tools that couple learning theory principles and developing technical skills are discussed including using learning management systems, flip teaching, collaborative learning, simulation-based e-learning, and peer assessment. Two blended-learning tools developed for surveying units are presented as examples. The first is an online interactive virtual simulation tool for leveling, one of the key tasks in surveying. The second is an e-assessment digital marking, moderation and feedback module. Surveys of students showed that they found the interactive simulation tool contributes to improving their understanding of required tasks. Students also found the e-assessment tool helpful in improving their performance and in helping them to focus on the objectives of each activity. In addition, the use of peer e-assessment to improve student learning and as a diagnostic tool for tutors is demonstrated.

Author [6] reported on an empirical research investigated four specific questions on blended instruction: 1) is there compatibility of blended instruction with accepted learning constructs? 2) Should there be any considerations of program audience that are better suited for this teaching method? 3) Is there evidence on the effectiveness of the pedagogy of blended learning itself? And finally 4) how are planned learning outcomes affected by this instructional method? In reviewing the empirical studies of others, it was found that the use of blended instruction is in fact very compatible with most of our commonly accepted practices of learning theory. In examining the factor of the audience in terms of successful learning results, there are noticeable differences that materialize, such as a generational demographic, the component of a student's intuitive learning quotient, and the pre-existing attitudes of the student on blended instruction. As far as the overall effectiveness of the pedagogy goes, it was found that this teaching method will lead to higher-level and higher-order thinking skills, a deeper appreciation of an academic community and an increase in self-regulated skills, such as time management. Finally, there is some evidence that suggests that in blended instruction, the use of concrete-sequential learning modules, the integration of greater visual imagery, and access to customized time allotment, there will be a positive impact on overall student outcomes. In summation, we can infer that when an instructor takes the effort and integrates well-constructed blended teaching principles aligned with individual students' needs, the final course outcomes will be just as or even more effective for most students compared to a direct face-to-face class environment.

New educational technologies prove to be capable of solving many problems in medical training. Students do not see e-learning as replacing traditional instructor-led training but as a complement to it, forming part of a blended-learning strategy. Innovations in e-learning technologies point toward a revolution in education, allowing learning to be individualized (adaptive learning), enhancing learners' interactions with others (collaborative learning), and transforming the role of the teacher. The integration of e-learning into medical education can catalyze the shift toward applying adult learning theory, where educators will no longer serve mainly as the distributors of content but will become more involved as facilitators of learning and assessors of competency. Still, their use in medical schools is being weighed down by certain factors [7].

Author [8] proposed an instructional design model for blended learning writing courses for English language learners (ELLs). It will do so by combining the main points of the cognitive load, activity, socio-cultural and transactional distance theories to present four tenets essential for optimal learning for ELLs: Structure, Environment, Experience, and People (SEEP). To do so, he first reviewed these four theories looking specifically at the ways in which they inform the SEEP instructional design model. The second section of his article then made recommendations for implementing and evaluating the SEEP model in instructional design practice for designing blended learning courses for this particular group. It is hoped that these principles can be used to inform the design of blended learning writing courses for ELLs, therefore improving teaching practices, and ultimately, increasing the effectiveness of the material.

In order to better understand the appropriate use of blended learning in an actual Information Technology course [9] examined an online communication as the link between established theory of learning and literature on e-learning. First, previously defined theoretical constructs that utilize communication as a facilitator for learning are considered. Then, using the interpretive standpoint, the authors examined data gathered from focus groups and interviews to weigh the experience of staff and students who were participants in a Blended Learning course. The results suggest that communication is both a challenge and an enabler for facilitating a successful blended learning course. Blended learning is not simply a matter of the combination of face-to-face and online instruction, but it has to have elements of social interactions. On the other hand; [10] discussed the challenges faced by those seeking to design effective blended learning. Using a 2-year case study involving cohorts of approximately 200 students, they demonstrated how Anthony Giddens structuration theory can provide a meta-framework for assisting educational designers in creating coherent blended learning experiences 
that reinforce intended learning outcomes. They called for educational designers to be sensitive to both their audience and the unintended and unanticipated consequences of their actions and shows how a holistic annual review framework can reinforce or suppress emergent behavior through unit development.

\section{BLENDED LEARNING AND HIGHER EDUCATION STUDENTS' SATISFACTION}

The term satisfaction is usually used to describe a happy or a pleased feeling because of something that some did or something that happened to him. It is the act of providing what is needed or desired; the act of satisfying a need or desire. The major factors that affect learning effectiveness are satisfaction with learning and teaching innovation. Innovation in this study is represented in the enhanced blended learning strategy used for teaching the learning theory course at the Arabian Gulf University. Satisfaction with learning is one of the major items to measure learning achievement. In addition to students' personal factors, satisfaction with learning can be affected by subject matter, the teaching method and the course instructor, the learning environment, and other factors.

Satisfaction with learning represents a key concern for higher education stakeholders. Authors [11] from the Open University mentioned that: with the higher education sector becoming an increasingly competitive market, student satisfaction has become an important component of Quality Assurance (QA) and Quality Enhancement (QE). In another study [12] from Pakistan examined the students' satisfaction in higher education in Pakistan. Their study focuses on the factors like teachers' expertise, courses offered, learning environment and classroom facilities. Students' response measured through an adapted questionnaire on a 5-point Likert scale. The sample size of the study consisted of 350 students belong to different private and public sector universities. The results of regression analysis revealed that all attributes have a significant and positive impact on students' satisfaction in higher education though with varying degree of strength. However, teachers' expertise is the most influential factor among all the variables, therefore it requires special attention of the policymakers and institutes. In Taiwan [13] conducted a study to examine the effect of the teaching quality of culinary arts teachers and student learning satisfaction on the academic performance of hospitality students. They surveyed the students in hospitality departments at universities in Taiwan. A total of $406(81.2 \%)$ valid questionnaires were received. Research results showed that there is a significant positive correlation between teaching quality of teachers and the learning satisfaction of students, between teaching quality of teachers and the academic performance of students, and between the learning satisfaction of students and the academic performance of students. The learning satisfaction of students has a mediating effect on the relationship between the teaching quality of teachers and the academic performance of students.

At the International Islamic University, Pakistan [14] studied the reliability and validity of the three dimensions of distance learning satisfaction, which are student-instructor interaction, instructor's performance, and course evaluation. They told us that; these dimensions can be understood as the way the course content is delivered, feedback and interactions take place with instructors, effectiveness of instructors, students learning experiences, workload and evaluation criteria in their distance courses, and convenience of the means of communication, the ease of system operation for the learners, and the quality of content the students receive.

To investigate graduate students' perceptions of their graduate college experiences [15] reported on study involved 1704 masters' and doctoral students across colleges and disciplines at a research university. They completed questionnaires reporting their perceptions of their teaching and advising faculty, academic programs, centralized services, social experiences, career preparation, and self-efficacy and identity development. Results are reported for the whole group as well as for subgroups by degree type (masters, doctoral), by point-in-program towards degree (entrance, mid-point, exit) and by disciplinary clusters (hard sciences, social sciences, arts, interdisciplinary). An overall pattern in trajectory of perceptions was highest at entrance, a drop at mid-point, and some recovery at end-of-program. Three characteristics were significantly different by the degree type, all higher for doctoral than masters' students: satisfaction with the program of study, satisfaction with the academic advisor; and perceptions of professional competence and identity development. Additionally, three characteristics were significantly different by point-in-program, all lowest at midpoint: satisfaction with overall graduate experience; satisfaction with the program of study; and perception of the career preparation. Significant interactions were demonstrated between degree type and point-in-program for: satisfaction with the academic advisor and the interaction in the academic community. Significant disciplinary differences were demonstrated for all perceptual characteristics "except" satisfaction with the program faculty and satisfaction with the career preparation. All students reported lower levels of interaction and involvement in the academic community than for any other variable.

Blended learning is an effective approach to instruction that combines features of face-to-face learning and computer-mediated learning. Authors [16] investigated the relationship between student perceptions of three types of interaction and blended learning course satisfaction. The participants included K-12 teachers enrolled in a graduate-level course. Results indicated that students (a) perceived interaction as important to their learning experiences and (b) were moderately satisfied in their blended learning course. The predictive model of student satisfaction including three types of interaction was reliable. Of the three types of interaction, the learner-content interaction was the strongest predictor of student satisfaction when the course design involved a low amount of collaborative activities. Additionally, student personality was found to be a vital factor for interaction and satisfaction in this type of course design. Students who reported having an extroverted personality noted more interaction and a higher level of student satisfaction than those who self-reported as 
introverted.

On the other hand [17] examined the perceptions of online master's students regarding their best learning experiences. The authors surveyed 86 graduate students concerning what helped them learn in the online environment. Results indicated that although graduate students learned using the same technological tools as undergraduates, they desired a deeper level of learning that requires more instructional forethought and planning. Student experiences were consistent with the constructivist theory, and implications for improving teaching based upon the constructivist theory are highlighted.

In a similar study [18] investigated graduate students' satisfaction levels with online learning associated with human (professor/instructor and instructional associate) and design factors (course structure and technical aspects) using a survey study. A total of 81 graduate master's students who majored in math and science education enrolled in an online math methods course (Conceptual Geometry) participated in this study. Data analysis revealed that; student satisfaction level is closely associated with clear guidelines on assignment, rubrics, and constructive feedback. In addition, student satisfaction level is related to professor's (or course instructor's) knowledge of materials.

Through the compilation of previous questionnaires implemented for other DL programs and newly defined research problems in one online survey tool, the author [19] seeks to identify the correlation of initial expectance and final assessment of the blended course. Survey results on a case study population showed that, even though the overall program seems to be appreciated, there are vast sections of the blended program that do not completely fulfill the expectations of the students. Furthermore, a need for further investigation and cross-referencing with respective studies is pointed out.

For disciplines heavily dependent upon traditional classroom teaching activities such as medicine and health sciences, incorporating new learning models may pose challenges for students and faculty. In an effort to innovate curricula, better align courses to required student learning outcomes, and address the call to redesign health professions education, Health Sciences Programs at The George Washington University (GWU) embarked on two faculty development initiatives to encourage adoption of online, blended, and technology-enhanced courses. Authors [20] described the Review, Refresh, and Revise (R3) program, which relies on the evidenced-based Quality Matters Higher Education Rubric and resources from the Supported Media for Administration and Teaching (SMART) Lab to develop and promote a pedagogical approach to course redesign. It also presents preliminary data evaluating the programs in terms of faculty satisfaction, student satisfaction, learning outcomes, and learner engagement. Data analysis indicated that faculty satisfaction with the R3 program and SMART Lab resources despite faculty concerns regarding the time commitment required by $\mathrm{R} 3$. It also indicated that both initiatives improved course quality, learning outcomes, and learner engagement. Analysis indicated that student satisfaction with course revisions in online and technology-enhanced courses, although student satisfaction in the first fully blended course varied, particularly with regard to whether students found the use of technology engaging or essential to learning. Further research is required to understand student responses to blended learning in health sciences.

Previous research on blended course offerings focuses on the addition of asynchronous online content to an existing course. While some explore synchronous communication, few control for differences between treatment groups [21]. The author investigated the impact of teaching a blended course, using a virtual, interactive, real-time, and instructor-led (VIRI) classroom, on student engagement, performance, and satisfaction. An experimental design with both a control group and a treatment group was adapted. Around 90 students in a large urban university are randomly assigned by the registrar to two sections of an introductory marketing course was adapted. Using a pre- and post-semester questionnaire, the study measures student engagement, performance, and satisfaction. There are no statistical differences in student performance between the control and treatment groups. The only student engagement factor with a statistically significant difference between groups is student interest in their courses. Compared with the control group, the treatment group appears to be more interested $(+10 \%)$ in their courses at the end of the semester. Finally, fewer than 2 in 10 students express dissatisfaction with their participation in a VIRI course. Blended course offerings are increasing in importance in marketing and business education. The study provides guidance for fine-tuning the features of those course offerings by demonstrating how a VIRI classroom leverages the capabilities of technology without compromising learning outcomes.

The relationship between student perceptions of blended learning courses and their in-course achievement was examined by [22]. The research was conducted at a large urban university that embarked on a major initiative to scale-up blended learning across its campus. Student perceptions $(\mathrm{N}=577)$ were assessed in four areas deemed important to the university: overall satisfaction with blended learning, convenience afforded by blended learning, sense of engagement in their blended course, and views on learning outcomes. Final course grade was the dependent variable and cumulative grade point average was the covariate in an ANCOVA design. A remarkably strong relationship was found between perceptions and grades. Compared with low achieving students, high achievers were the most satisfied with their blended course, would take one again, and preferred the blended format more over fully face-to-face or online. High achievers also found blended courses more convenient, more engaging, and they felt that they learn key course concepts better than in other traditional face-to-face courses they have taken. An implication of the study is that low achievers may not be able to cope with the blended environment as well their high-achieving peers. Therefore, when scaling up blended learning institutions may want to consider offering students a choice of whether to enroll in blended or fully face-to-face course sections where feasible, especially in subject areas that students find difficult.

Authors [23] explored the effect of incorporating blended 
learning with Facebook and peer assessment for English for Business Communication course for college students. A total of 111 students from a public technological university participated in this study. The participants were divided into three Facebook site groups. A mixed method consisting of qualitative and quantitative approaches was employed to analyze the collected data, including the pre- and post-tests, qualitative data of peer assessment on Facebook sites, interview, a student self-efficacy scale, and a self-developed satisfaction survey questionnaire. The findings of this study indicated that incorporating Facebook in the English for Specific Purposes (ESP) course can effectively assist college students in learning business communication English. Students can improve their professional knowledge not only from the in-class instruction but also through peer assessing on Facebook. Additionally, the blended learning approach can significantly enhance the students' learning motivation and interest. Finally, some useful instructional strategies are provided to educators and practitioners in the English education field.

In 2013, authors [24] investigated the differences in perceived student satisfaction in blended and online learning environments based on personality type. A total of 72 graduate students enrolled in blended and online courses at two research universities in the United States completed an abbreviated online version of the Myers-Briggs Type Indicator (MBTI[R]) and an online student satisfaction questionnaire. Overall, results indicate participants were satisfied with courses delivered in both environments. Analyses revealed several significant differences in perceived student satisfaction with certain elements in blended and online courses based on personality type.

In his Ph.D. project, [25] evaluated graduate orientation programs offered at private institutions of higher education in a New England state. Matriculated master's degree candidates participated in a survey to determine if participation in graduate orientation influenced first-semester satisfaction with their college choice. Theoretical frameworks of Maslow (1954) [26], the hierarchy of needs, and of Schlossberg, Waters, and Goodman (1995) [27], transition theory, were utilized for the research. Participation, dependent variable, was explored for this study to seek its influence on satisfaction with the graduate institutional choice. Secondary predictor variables of residency, age, gender, and enrollment were further explored to assess covariate influence on satisfaction with the institutional choice at the graduate level. A quantitative design with a survey instrument was employed in this study. A 78-item survey instrument was administered to first-semester master's degree students $(\mathrm{N}=135)$. Analysis of variance (ANOVA) and Scheffe Post-Hoc Test was conducted on participation and satisfaction. Data analysis revealed a significant difference in satisfaction between students who participated in all of the orientation and students who did not participate fully. Hierarchical regression analysis was conducted on the covariates. The model revealed that a statistical difference existed to a varying degree in those who attended all of orientation, some of the orientation, or none of orientation as it related to satisfaction with institutional choice with gender found to be significant when analyzed. The findings from this study may have ramifications for those planning and implementing policies and activities for graduate student populations, specifically those who seek to improve graduate student satisfaction with college choice, graduate orientation programs, and institutional and alumni affiliation programs for graduate students.

In 2011, [28] provided a brief review of blended learning as a didactic method and discussed the issues and challenges of using blended learning models in post secondary education. They addressed challenges faced by large classrooms with a diverse student body, and the ways blended learning models can help alleviate those concerns (i.e. technologically savvy students, the need for course scheduling flexibility). In addition, a case study of blended learning in higher education in the context of a unique first year Introductory Psychology program at McMaster University was discussed. Lastly, the important learning benefits offered by blended learning systems, along with the potential barriers to their implementation was addressed.

The factors that influence the post-adoption satisfaction of educators with e-learning systems were examined by [29]. Based on the expectation-confirmation framework, a research model that demonstrates how post-adoption beliefs affect post-adoption satisfaction was proposed. The model was tested at a university by educators $(n=175)$ who use an e-learning platform to conduct their teaching. The results suggested that post-adoption satisfaction is driven by confirmation, perceived system quality, perceived usefulness, perceived work compatibility and perceived support. These core determinants of satisfaction explained around $83 \%$ of the total variance of satisfaction in this study.

Author [30] analyzed how satisfaction differs across the traditional and blended learning methods. Altogether, 21 courses for graduate and postgraduate engineering students were evaluated. Several variables and their relationship with student satisfaction in the first year, with all courses delivered in the traditional mode, were compared with student satisfaction in the second year, which had the same courses delivered in blended mode. Results suggested that student satisfaction is greater in blended courses than in face-to-face courses. This can be explained because the levels of class attendance, motivation, and collaboration with classmates were higher in blended learning than in classroom instruction. In addition, class attendance, access to teachers, collaboration with classmates and motivation were found to be leading predictors of student satisfaction in blended environments.

There are many reasons behind picking blended learning over other learning strategies. Blended learning approaches can enrich the pedagogy, facilitate access to knowledge, lead to more social interactions, reduce const, empower students learning motivation, lead to high level of satisfaction with learning, and make the learning activities enjoyable by the students.

The goal of the present study is to develop an enhanced blended learning strategy for teaching a learning theory graduate course at the Arabian Gulf University and assess its impact on distance teaching \& training program students' satisfaction with blended learning. 


\section{A. AGU Distance Teaching \& Training Program Learning Theory Module}

Educators need to study learning theory so that they can be more effective in their education and teaching. According to [31], learning theories suggest a set of instructional principles that can guide the practice of teaching and the design of learning material and environments. It is important that learning design practices, must do more than merely accommodate the perspective of different learning theories, they should also support the creation of powerful learning environments from constructivism, instructional design, and technology implications for transforming distance learning. The theories differ significantly in the perspectives on learning, though each has influenced and shaped instructional methods and practices to some degree. A course in learning theory can help distance learning developers to deal with the different schools of learning and be familiar with the principles of learning driven from these schools and its relevance for designing and developing distance learning.

Learning theory is the first module in the Distance Teaching and Training Post Graduate Diploma \& Master program at the Arabian Gulf University. The module begins with an overview of three broad groups of learning theory: behaviorist, cognitive and social, then concentrates on constructivism as a theory of learning that underpins the writing of open and distance learning material, whether in print or online.

The module will also look at how the learner learns and at how learners are motivated. And then make the connection between the experiential learning cycle and learning styles, before explaining the importance of accommodating different learning styles within the design of open and distance learning materials. The module also applies these ideas in order to identify the principles of successful learning and good writing. In particular, it looks at the theoretical aspect of aims and objectives with an overview of a particular taxonomy of learning objectives that will be used during this program. The module also considers the difference between aims and objectives and their link with the assessment. The 6th unit of the learning theory module clarifies some points related to connectivism as a theory of digital age. Connectivism is a theoretical framework for understanding interment based learning. The final unit of the module clarifies some of the terminologies that have been used in the module and explores the various terms used to describe learning at a distance, such as 'open', 'distance', 'flexible', 'e-learning' and 'online learning'.

After an initial period of one-week intensive on-campus teaching, using the module workbook, the student will be expected to engage in discussion and further work with his/ her colleagues. He/she should then use the material for his/her private study. The main features of the module that distance students need to be aware of before he/she begins studying the module are:

1) It is intended to be completed by the student during the first on-campus week and then at his/her own pace within one month.

2) It is self-contained but the students should be aware that the area of distance learning, especially online learning, is subject to constant change. It is, therefore, important that he/she carry out reading and research around the subject. He/she will find a list of references at the end of most units, often including websites.

3) Each of the 7 units begins with a list of learning objectives. These describe the skills and knowledge that students should gain from working through the unit.

4) As the student works through the module he/she will find activities to do. These aim to teach key areas of a topic, give the student practice in using the skills or knowledge he/she has gained, or get him/her to think about the implications of the topic. He/she should try to carry out all the activities. Some activities are reflective, and he/ she should discuss the questions raised in these with his/her colleagues during the three weeks following the taught element. The process of engaging in the activity is as important as the product of the activity.

5) Feedback is provided immediately after the activities. The student should take careful note of such feedback, as it not only gives him/her a response but also provides $\mathrm{him} /$ her with further guidance on the topic. This is why, however much you may be tempted, the student should not omit an activity. He/she might miss out on some valuable feedback. As he/she will discover, activities and feedback are two of the essential elements of a distance learning program. Some of this feedback may be developed by the teacher during the first week on campus.

6) The teacher will also provide some questions based on each of the units. By attempting these, the learner will be able to check whether he/she has achieved the learning objectives for that unit.

The module will cover the following: 1) theories of learning, 2) constructivism, 3) learning styles and motivation, 4) active learning, 5) aims and objectives, 6) connectivism as a learning theory for the digital age, and 7) terminology.

\section{ThE STUdy}

\section{A. Research Problem}

Learning theory is the first module in the Arabian Gulf University post-graduate program leading to a high diploma and master degree in distance teaching and training. The aim of the course is to intrude distance teaching \& training candidates to the different school of learning and help them to deal with the principles of learning driven from these theories for developing face-to-face, blended learning, and online learning material. Some of the complex issues in the field of learning theory for distance education include the availability of appropriate textbooks translated into the Arabic language, and classroom resources and learning activities all deliver in English and oriented to education and training. Most of the fresh students who joined the program face with some difficulties to capture the idea of the course when they try to transfer the theory into practice. The course content, the workload and the language of instruction (English) represent the main difficulties addressed by the students who studied the course before the academic year 
2014/2015. The problem faces the course instructor is the need to meet the standards and develop his students' competencies to a standardized level of distance learning material writing and development. So there a need to propose an enhanced blended learning strategy for teaching learning theory module and there a need for assessing the impact the proposed strategy on empowering the learning theory candidates satisfaction with the blended learning experience.

The main question addressed by this study is that: what is the proposed blended learning strategy like? And what is its impact on distance teaching and training program students' satisfaction with blended learning?

Emerging from this question the following sub-questions:

1) What is the proposed enhanced blended learning strategy like?

2) What is the impact of the proposed blended learning strategy on distance teaching and training program students' satisfaction with learning?

3) Does the level of satisfaction with learning change according to the student's program of study (diploma, master)?

4) Does level of satisfaction with learning change according to student's gender (male, female)?

5) What are the most (enjoyed and un-enjoyed) topics of the blended learning by the participants?

6) What are the participants' recommendations for improving the course outcomes in the future?

\section{B. Purpose of the Study}

The present study is undertaken to develop an enhanced blended learning strategy and assess its impact on empowering Arabian Gulf University distance teaching and training program students' satisfaction with learning the course material and the learning process in general. Synchronic and asynchrony social communications tools like Facebook and WhatsApp seem to be the most acceptable communication tools for enhancing blending learning delivery that makes the learning experience enjoyable by the post graduate learners. Putting this into consideration it was decided to explore developing an enhanced blended learning strategy and testing its effects on subjects' satisfaction with learning.

\section{Limitations}

There were two limitations to the current study. First, there were no pre-intervention measures of the participants' satisfaction with blended learning during their post graduate program work. This was because the learning theory module was the first graduate course to be taught in the master and the diploma level. In fact the majority of the participants were taught on a module based and practiced blended learning for the first time in their education. The experience is totally a new one for them. Generally, to implement the enhanced blended learning in post-graduate programs and use the social communications tools like WatsApp need good planning and previous preparation.

\section{METHOD AND PROCEDURES}

\section{A. Research Design}

The implementation of this is research is based on an experimental research methodology with a quasi -experiential research design; it is a one group research design. The study developed the proposed blended learning strategy, utilized the strategy for teaching the learning theory module, and then assessed the impact of the proposed strategy on subjects`satisfaction with learning. It is worth mentioning that; the independent research variable is the proposed enhanced blended learning strategy and the dependent variable is the satisfaction with learning.

\section{B. Population and Sample}

The population of the study consisted of all distance teaching program students at the Arabian Gulf University who supposed to study learning theory module.

The participants were a graduate class of 22 master and diploma (26-to-38-year-olds) at the Arabian Gulf University, distance teaching \& training program in the Kingdom of Bahrain. This study is mainly intended to explore the use of the proposed enhanced blended learning approach on distance learning high diploma and master students satisfaction with learning.

Concerning the program of the study, 14 (51.9\%) registered for the post graduate diploma in distance teaching \& training, and 12 (48.1) for the master degree in distance teaching and training. Table I displays deceptive statistics of subjects' characteristics.

\section{Procedures}

TABLE I: CHARACTERISTICS OF THE PARTICIPANTS

\begin{tabular}{l|l}
\hline \hline Variable & $\%$ \\
\hline \hline Gender & 25.0 \\
Male & 75.0 \\
\hline Age & \\
Mean & 32.47 \\
Std. Deviation & 03.64 \\
Maximum & 38.00 \\
Minimum & 26.00 \\
\hline Nationality & \\
Bahrain & 20.0 \\
Saudi Arabia & 35.0 \\
Kuwait State & 45.5 \\
\hline University degree & \\
\hline Educational Technology \& & 25.0 \\
Computer Education & \\
Computer science \& engineering & 11.1 \\
Sciences & 03.7 \\
Humanaties\& Languages & 40.8 \\
\hline Learning style & \\
\hline Theorists & 33.4 \\
Activists & 11.1 \\
Pragmatists & 14.8 \\
Reflectors & 40.7 \\
\hline Program of study & \\
\hline Postgraduate diploma & 51.9 \\
Master & 48.1 \\
\hline \hline
\end{tabular}

The study lasted for one month started on 18th of September and ended on the 17th of October 2015 in the first semester of the academic year 2015/2016, containing 4 instructional weeks. The first week of the module was an intensive face-to-face instruction i.e. (in campus instruction). From Weeks 2 to week 4, the proposed enhanced blended learning based on Moodle LMS and WatsApp were 
implemented. During the last three weeks of the module (course) seventh short quizzes, learning theory scientist assignment, AGU course assignment, motivating a distance learning assignment, the learning theory post test, and the satisfaction with learning survey were conducted in the last week.

\section{Research Instruments}

For data collection, the study used the following instruments:

1) Students registration records for collecting subjects demographic information,

2) Honey and Mumford's learning styles questionnaire. It is one of the best-known taxonomies of learning styles, and it was developed by [32], and is based on responses to a questionnaire. The questionnaire can be used to help an individual to discover his preferred learning style(s). According to the authors [32] learning styles can be classified into four groups. These include theorists, activists, pragmatists and reflectors. Table II presents short descriptions of the four learning styles.

TABLE II: SHORT DESCRIPTIONS OF HONEY AND MUMFORD (1992) LEARNING STYLES

\begin{tabular}{ll}
\hline \hline Learning style & \multicolumn{1}{c}{ Description } \\
\hline \multirow{3}{*}{ Theorists } & $\begin{array}{l}\text { A theorist thinks things through in a logical } \\
\text { way, grouping facts into coherent theories. } \\
\text { They are perfectionists who like to analyze } \\
\text { and synthesize and are fond of theories, } \\
\text { models, taxonomies and so on. They want to } \\
\text { know if things make sense. } \\
\text { An activist, as the name suggests, like new } \\
\text { experiences, is open-minded and will tend to } \\
\text { rush into things. They are always very busy } \\
\text { and love change and crises. } \\
\text { Like the activists, the pragmatists like to seek } \\
\text { out new ideas, but they also like to experiment } \\
\text { with them and test whether they work in } \\
\text { practice. } \\
\text { A reflector likes to collect data, think about } \\
\text { and analyze it thoroughly, and then reach a } \\
\text { conclusion, which they will put off for as long } \\
\text { as possible. }\end{array}$ \\
\hline \hline
\end{tabular}

3) A satisfaction with learning instrument which used for collecting data related subjects satisfaction with the learning experience and learning devices. This instrument composed of 32 items asking the participant to report on his satisfaction with the learning expectance. The items (questions) were distrusted into three groups that create subjects satisfaction with learning i.e. (the teaching methods, the module content and the module instructor). Table III shows the scale dimension, the number of items and the validity constant.

Table III, shows that the total computed alpha values for all dimensions and the whole scales are acceptable to confirm the suitability of the scale for measuring the learners' satisfaction with learning.

4) AGU satisfaction with learning questionnaire. A satisfaction with a course evaluation questionnaire developed by the National Commission for Academic Accreditation \& Assessment- NCAAA [33] and administrated by the Quality and Excellence Censer at
AGU is administrated at the end of the course. This instrument composed of two parts, a Likert 5 point scale composed of 26 questions which ask the candidate to report on his satisfaction with the course material and the learning experience. It is worth mentioning that the 26 questions are distributed into four dimensions created the satisfaction with learning. These components are; the course teaching plan (3 items); teaching effectiveness (17) items, judging the course value (5 items) and the course overall evaluation (one item). Data was collected and analyzed by the AGU Quality and Excellence Censer. For the purpose of the present study, only data analysis results represented in Fig. 2 is used.

TABLE III: SCALE COMPONENTS, NUMBER OF ITEMS IN EACH DIMENSION AND DIMENSION RELIABILITY COEFFICIENT

\begin{tabular}{lcc}
\hline \hline $\begin{array}{l}\text { The scale } \\
\text { component }\end{array}$ & $\begin{array}{c}\text { Number of } \\
\text { questions }\end{array}$ & $\begin{array}{c}\text { Computed Cronbach's } \\
\text { Alpha }\end{array}$ \\
\hline $\begin{array}{l}\text { The teaching } \\
\text { methods, } \\
\text { Te module content }\end{array}$ & 13 & .884 \\
$\begin{array}{l}\text { Te module } \\
\text { instructor } \\
\text { The scale }\end{array}$ & 10 & .806 \\
\hline \hline
\end{tabular}

\section{The Study Results}

The present study is intended to assess the impact of an enhanced blended strategy used for teaching a graduate course in learning theory on distance teaching and training program students at the Arabian Gulf University satisfaction with the learning experience.

\section{A. Results Related to Question 1}

Question 2 addressing the following: what is the proposed enhanced blended learning strategy like?

As stated earlier; one aim of this study is to develop an enhanced blended learning strategy and utilize this strategy for teaching the learning theory module. The study is going to create a blueprint of the learning activities that will transfer, develop, and reinforce the skills and knowledge formulated in the performance objectives, as well as sequencing the items in the blueprint in the order that will provide the best learning environment.

The purpose of the proposed enhanced blended learning strategy is to outline how instructional activities will relate to the accomplishment of the module learning objectives. The enhanced blended learning strategy used in this study was an activity based one and composed of the following components (Fig. 1 illustrates the proposed blended learning strategy).

The components of the proposed blended learning strategy are as follows:

1) Intensive face -to-face (f2f), in campus instruction

2) Personalized \& collaborative learning using AGU MOODLE course campus, internet open learning resources and WatsApp discussion guided by the course instructor.

3) Learning Theory Module assignments, preparation for the final exam and the learning theory scientist 
presentation.

4) Finalizing course assignments, submission, preparation for the final exam and the learning theory scientist presentation.

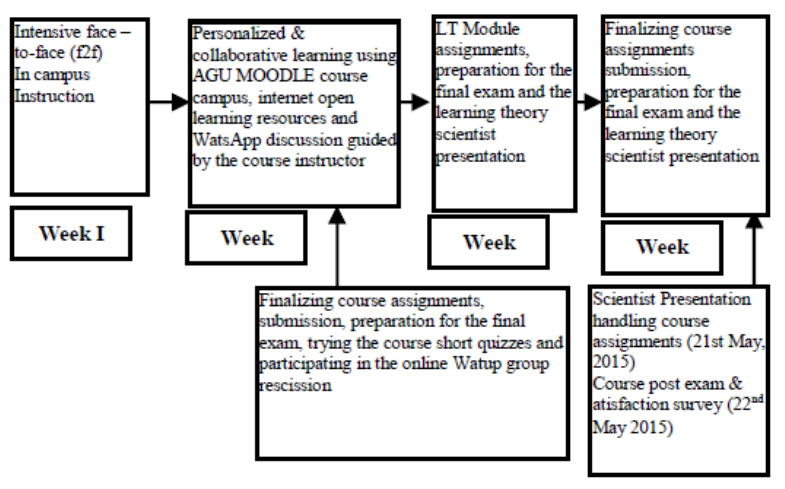

Fig. 1. The proposed blended learning strategy.

\section{B. Results Related to Question 2}

Question 2 addresses the following: what is the impact of the proposed enhanced blended learning strategy on distance learning students' satisfaction with learning?

Satisfaction with learning data is collected at the end of the course by administrating a satisfaction instrument answered by 19 out of the 22 course-candidates. Data coded and analyzed by using the SPSS Ver. 19 analysis software, results related to each question/hypothesis are tabled and arranged as shown in the following programs. Table IV shows the results of the decretive statistic of the satisfaction with learning instrument.

TABLE IV: DESCRIPTIVE STATISTICS OF SATISFACTION WITH LEARNING

\begin{tabular}{lcccc} 
& \multicolumn{3}{c}{ SCALE } & \\
\hline \hline $\begin{array}{l}\text { Satisfaction } \\
\text { Components }\end{array}$ & $\mathrm{N}$ & Mean & SD & $\begin{array}{l}\text { Level of } \\
\text { Judge }\end{array}$ \\
\hline $\begin{array}{l}\text { The Teaching } \\
\text { Method }\end{array}$ & 18 & 4.62 & .37 & Very high \\
\hline $\begin{array}{l}\text { The module } \\
\text { content }\end{array}$ & 19 & 4.50 & .41 & Very high \\
\hline $\begin{array}{l}\text { The module } \\
\text { instructor }\end{array}$ & 19 & 4.83 & .28 & Very high \\
\hline The course & 18 & 4.50 & .31 & Very high \\
\hline \hline
\end{tabular}

Results of Table IV show the following:

1) All satisfaction with learning instrument diminutions (the teaching method, the module content, and the module instructor) as well as the whole module scored a very high level of satisfaction.

2) Subjects satisfaction with the course (module) instructor scored the highest level $(\mathrm{M}=4.83, \mathrm{SD}=.28)$, then came subjects`satisfaction with the teaching method which a blended learning $(\mathrm{M}=4.62, \mathrm{SD}=.37)$, and the module content $(\mathrm{M}=4.50, \mathrm{SD}=.41)$.

3) For the whole course (module) the average satisfaction is $(\mathrm{M}=4.50, \mathrm{SD}=.31)$ which is judged as a very high degree of satisfaction with the course as well as the teaching approach.

To test where the computed means of satisfaction were significance or not, one sample t-test was conducted comparing the means of the satisfaction dimensions to the normal mean of satisfaction $\mathrm{m}=3$ ). Table $\mathrm{V}$ one sample T-test results
From Table $\mathrm{V}$ results for all satisfaction with learning dimensions (the teaching method, the module content, the module instructor as well as the whole course) means compared to the normal satisfaction level $(\mathrm{m}=3$ out of 5$)$ was statistically different, at the .05 level of significance, from the normal value of 3 . Results show that the proposed blended learning strategy led to a very high level of satisfaction with the learning experience among distance teaching and training diploma and master degree capitates who study learning theory course at the Arabian Gulf University.

TABLE V: SATISFACTION WITH BLENDED LEARNING ONE-SAMPLE TEST RESUltS (TEST VALUE M=3)

\begin{tabular}{|c|c|c|c|c|c|c|}
\hline \multirow[t]{2}{*}{$\begin{array}{l}\text { Satisfaction } \\
\text { Components }\end{array}$} & \multirow[t]{2}{*}{$\mathrm{t}$} & \multirow[t]{2}{*}{ df } & \multirow[t]{2}{*}{$\begin{array}{l}\text { Sig. } \\
\text { 2-taile } \\
\text { d }\end{array}$} & \multirow[t]{2}{*}{$\begin{array}{l}\text { Mean } \\
\text { Diff, }\end{array}$} & \multicolumn{2}{|c|}{$\begin{array}{l}\text { 95\% Confidence } \\
\text { Interval of the } \\
\text { Difference }\end{array}$} \\
\hline & & & & & Lower & $\begin{array}{l}\text { Uppe } \\
\text { r }\end{array}$ \\
\hline $\begin{array}{l}\text { The Teaching } \\
\text { Method }\end{array}$ & 18.724 & 17 & .000 & 1.61966 & 1.4372 & 1.8022 \\
\hline $\begin{array}{l}\text { The module } \\
\text { content }\end{array}$ & 15.993 & 18 & .000 & 1.49708 & 1.3004 & 1.6937 \\
\hline $\begin{array}{l}\text { The module } \\
\text { instructor }\end{array}$ & 28.374 & 18 & .000 & 1.82632 & 1.6911 & 1.9615 \\
\hline The course & 20.236 & 17 & .000 & 1.49653 & 1.3405 & 1.6526 \\
\hline
\end{tabular}

\section{Results Related to Question 3}

Question 3 addresses the following: Does level of satisfaction with learning change according to subject's' university degree (educational -non-education)?. Table VI shows one way-ANOVA test results.

TABLE VI: SATISFACTION WITH LEARNING ANOVA RESULTS (UNIVERSITY DEGREE)

\begin{tabular}{|c|c|c|c|c|c|c|}
\hline \multicolumn{2}{|c|}{$\begin{array}{l}\text { Satisfaction } \\
\text { Components }\end{array}$} & $\begin{array}{l}\text { Sum of } \\
\text { Squares }\end{array}$ & $\mathrm{df}$ & $\begin{array}{l}\text { Mean } \\
\text { Square }\end{array}$ & F & Sig. \\
\hline \multirow{3}{*}{ 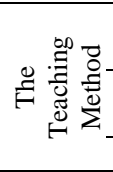 } & $\begin{array}{l}\text { Between } \\
\text { Groups }\end{array}$ & .006 & 1 & .006 & .042 & .840 \\
\hline & $\begin{array}{l}\text { Within } \\
\text { Groups }\end{array}$ & 2.284 & 16 & .143 & & \\
\hline & Total & 2.290 & 17 & & & \\
\hline \multirow{3}{*}{ 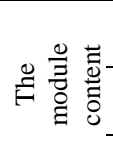 } & $\begin{array}{l}\text { Between } \\
\text { Groups }\end{array}$ & .000 & 1 & .000 & .000 & .988 \\
\hline & $\begin{array}{l}\text { Within } \\
\text { Groups }\end{array}$ & 2.997 & 17 & .176 & & \\
\hline & Total & 2.997 & 18 & & & \\
\hline \multirow{3}{*}{ 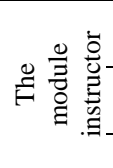 } & $\begin{array}{l}\text { Between } \\
\text { Groups }\end{array}$ & .028 & 1 & .028 & .337 & .569 \\
\hline & $\begin{array}{l}\text { Within } \\
\text { Groups }\end{array}$ & 1.389 & 17 & .082 & & \\
\hline & Total & 1.417 & 18 & & & \\
\hline \multirow{3}{*}{ 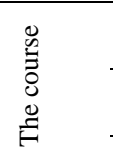 } & $\begin{array}{l}\text { Between } \\
\text { Groups }\end{array}$ & .006 & 1 & .006 & .059 & .810 \\
\hline & $\begin{array}{l}\text { Within } \\
\text { Groups }\end{array}$ & 1.667 & 16 & .104 & & \\
\hline & Total & 1.674 & 17 & & & \\
\hline
\end{tabular}

From (Table VI) we can see that the significance values are $0.840,0.988,0.569$ and 0.810 respectively (i.e., for the teaching method $\mathrm{p}=0.840$, for the module content $\mathrm{p}=0.988$, for the course instructor $\mathrm{p}=0.569$, and for the whole course $\mathrm{p}=0.810$ ) which are above 0.05 . And, therefore, there are no statistically significant differences in the means of the satisfaction with learning components between subjects according to their university degree (educational - none educational) the educational and none education degree. 


\section{Results Related to Question 4}

Question 4 addresses the following: Does level of satisfaction with learning change according to subject's gender (male-female)? Table VII shows gender one way-ANOVA test results.

From (Table VII) above we can see that the significance values are $0.684,0.737,0.679$ and 0.747 respectively (i.e., for the teaching method $\mathrm{p}=0.684$, for the module content $\mathrm{p}=0.737$, for the module instructor $\mathrm{p}=0.679$, and for the whole module $\mathrm{p}=0.747$ ) which are above $\mathrm{p}=0.05$, and, therefore, there are no statistically significant differences in the means of the satisfaction with the blended learning components between subjects according to their gender (male-female).

\begin{tabular}{|c|c|c|c|c|c|c|}
\hline \multicolumn{2}{|c|}{$\begin{array}{l}\text { Satisfaction } \\
\text { Components }\end{array}$} & $\begin{array}{l}\text { Sum of } \\
\text { Square }\end{array}$ & df & $\begin{array}{l}\text { Mean } \\
\text { Square }\end{array}$ & $\mathrm{F}$ & Sig. \\
\hline \multirow{3}{*}{$\begin{array}{l}\text { The } \\
\text { Teaching } \\
\text { Method }\end{array}$} & $\begin{array}{l}\text { Between } \\
\text { Groups }\end{array}$ & .320 & 4 & .080 & .579 & .684 \\
\hline & $\begin{array}{l}\text { Within } \\
\text { Groups }\end{array}$ & 1.658 & 12 & .138 & & \\
\hline & Total & 1.978 & 16 & & & \\
\hline \multirow{3}{*}{$\begin{array}{l}\text { The } \\
\text { module } \\
\text { content }\end{array}$} & $\begin{array}{l}\text { Between } \\
\text { Groups }\end{array}$ & .395 & 4 & .099 & .499 & .737 \\
\hline & $\begin{array}{l}\text { Within } \\
\text { Groups }\end{array}$ & 2.574 & 13 & .198 & & \\
\hline & Total & 2.968 & 17 & & & \\
\hline \multirow{3}{*}{$\begin{array}{l}\text { The } \\
\text { module } \\
\text { instructor }\end{array}$} & $\begin{array}{l}\text { Between } \\
\text { Groups }\end{array}$ & .216 & 4 & .054 & .585 & .679 \\
\hline & $\begin{array}{l}\text { Within } \\
\text { Groups }\end{array}$ & 1.200 & 13 & .092 & & \\
\hline & Total & 1.416 & 17 & & & \\
\hline \multirow{3}{*}{$\begin{array}{l}\text { The whole } \\
\text { course }\end{array}$} & $\begin{array}{l}\text { Between } \\
\text { Groups }\end{array}$ & .224 & 4 & .056 & .485 & .747 \\
\hline & $\begin{array}{l}\text { Within } \\
\text { Groups }\end{array}$ & 1.385 & 12 & .115 & & \\
\hline & Total & 1.609 & 16 & & & \\
\hline
\end{tabular}

\section{E. Results Related to Question 5}

Question 5 addresses the following: Does the level of satisfaction with learning among subjects change according to subject's learning style (theorist, activist, reflector, and pragmatist)?. Table VIII shows learning style one way-ANOVA test results.

From (Table VIII) above we can see that the significance values are $0.287,0.688,0.357$ and 0.477 respectively (i.e., for the teaching method $\mathrm{p}=0.287$, for the module content $\mathrm{p}=0.688$, for the module instructor $\mathrm{p}=0.357$ and for the whole module $\mathrm{p}=0.477$ ) which are above $\mathrm{p}=0.05$, and, therefore, there are no statistically significant differences in the means of the satisfaction with learning components between subjects according to subjects learning style (theorist, activist, reflector, and pragmatist).

\section{F. Results Related to Question 6}

Question 6 addresses three open-ended questions asking the participants to evaluate the proposed blended learning strategy by respond to following questions:

1) What is the best of the course you much like?

2) What is the west of the course that you did not like?

3) What are your suggestions for improving the course in the future?

Twenty (20) candidates out of the 22 participants who enrolled in the study have answered the satisfaction with the learning instrument administrated at the end of the course by the Arabian Gulf University Quality \& Excellence Centre. Data analysis shows a very high degree of satisfaction with the learning theory course (i.e. overall satisfaction is around 91\%), as s shown in Fig. 2, below.

TABLE VIII: SATISFACTION WITH LEARNING ANOVA RESULTS (LEARNING STYLE: THEORIST, ACTIVIST, REFLECTOR, AND PRAGMATIST)

\begin{tabular}{|c|c|c|c|c|c|c|}
\hline $\begin{array}{l}\text { Satisfaction } \\
\text { Components }\end{array}$ & & $\begin{array}{l}\text { Sum of } \\
\text { Squares }\end{array}$ & df & $\begin{array}{l}\text { Mean } \\
\text { Square }\end{array}$ & F & Sig. \\
\hline \multirow[t]{3}{*}{$\begin{array}{l}\text { The teaching } \\
\text { method }\end{array}$} & $\begin{array}{l}\text { Between } \\
\text { Groups }\end{array}$ & .558 & 3 & .186 & 1.402 & .287 \\
\hline & $\begin{array}{l}\text { Within } \\
\text { Groups }\end{array}$ & 1.726 & 13 & .133 & & \\
\hline & Total & 2.284 & 16 & & & \\
\hline \multirow[t]{3}{*}{$\begin{array}{l}\text { The module } \\
\text { content }\end{array}$} & $\begin{array}{l}\text { Between } \\
\text { Groups }\end{array}$ & .287 & 3 & .096 & .500 & .688 \\
\hline & $\begin{array}{l}\text { Within } \\
\text { Groups }\end{array}$ & 2.679 & 14 & .191 & & \\
\hline & Total & 2.966 & 17 & & & \\
\hline \multirow[t]{3}{*}{$\begin{array}{l}\text { The module } \\
\text { instructor }\end{array}$} & $\begin{array}{l}\text { Between } \\
\text { Groups }\end{array}$ & .277 & 3 & .092 & 1.167 & .357 \\
\hline & $\begin{array}{l}\text { Within } \\
\text { Groups }\end{array}$ & 1.108 & 14 & .079 & & \\
\hline & Total & 1.385 & 17 & & & \\
\hline \multirow[t]{3}{*}{ The course } & $\begin{array}{l}\text { Between } \\
\text { Groups }\end{array}$ & .279 & 3 & .093 & .879 & .477 \\
\hline & $\begin{array}{l}\text { Within } \\
\text { Groups }\end{array}$ & 1.377 & 13 & .106 & & \\
\hline & Total & 1.656 & 16 & & & \\
\hline
\end{tabular}

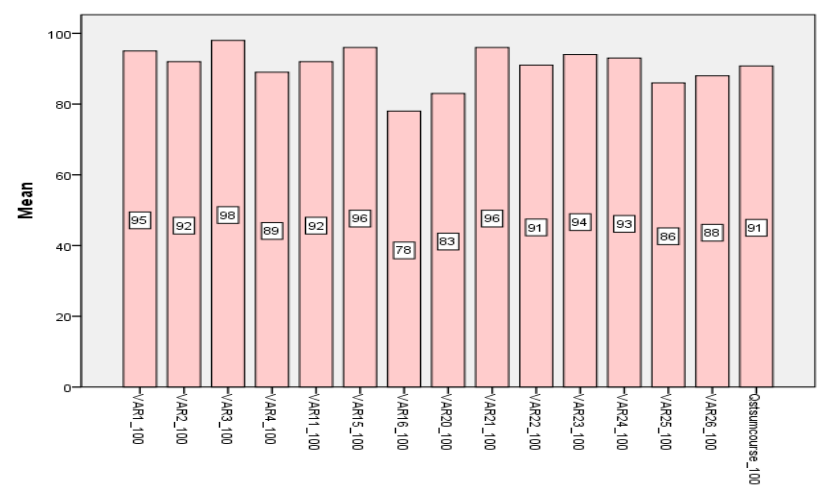

Fig. 2. Subjects`satisfaction with learning theory module.

The results related to open - ended questions summarized in Table IX next page.

\section{DISCUSSIONS}

University instructors are encouraged to innovate and use new learning strategies so as to deliver their instruction expertise that helps their students to feel more satisfied. For successful instruction, it is recommend adapting blended learning strategies with a rich learning environment that introduce truly appropriate instructional methods and facilitate the construction of knowledge by students. Using a rich learning environment with varsities of learning resources that suit students of differential backgrounds, beliefs, attitudes, and learning styles, however, can accelerate the learning process. The present study was interested in identifying elements of the learning environment possibly linked to better student learning.

The present study is developed to assess the impact of an 
enhanced blended learning strategy on graduate student satisfaction with learning. The components of the blended learning experience under investigation are the teaching method, the course content and the course instructor. In this study, the teaching method is an enhanced blended learning strategy which integrates face -to-face presentation with online material and WatsApp discussions on the course content. The course content is a 7 units` module covering the major known learning theories and its applications in the educational field. These include behaviorism learning theory, cognitive learning theory, social \& experiential learning theories, constructivism learning theory, motivation theory and learning style and connectivism as a learning theory for the digital age. The online components of the course were set out in Moodle learning environment owned by the Arabian Gulf University, all the communications tools that facilitate interactions and knowledge exchange was installed and put to use for the students in addition to complementary WatsUp group nominated as learning theory.

TABLE IX: RESULTS OF THE STUDY ON THE OPEN-ENDED QUESTIONS ABOUT THE COURSE

\begin{tabular}{|c|c|}
\hline Question & Subjects responses \\
\hline \multirow{4}{*}{$\begin{array}{l}\text { What is the best } \\
\text { of the course } \\
\text { you much like? }\end{array}$} & $\begin{array}{l}\text { 1. The course relates the theory to my own } \\
\text { learning. }\end{array}$ \\
\hline & $\begin{array}{l}\text { 2. The course topics presented in logical } \\
\text { sequence. }\end{array}$ \\
\hline & $\begin{array}{l}\text { 3. The course instructor knows how to } \\
\text { motivate his students in addition to his } \\
\text { high mastery of the course content. }\end{array}$ \\
\hline & $\begin{array}{l}\text { 4. The learning strategy is making the } \\
\text { course very interesting and full of } \\
\text { interactions. }\end{array}$ \\
\hline
\end{tabular}

5. The constructivism theory of learning as well as dealing with your students learning styles are of great interest for distance learning designers.

6. The course activities help the student to master the course objectives.

7. Is considered to be the core of the field distance teaching \& training.

8. Cooperation of the course instructor and his keenness to provide the best of the learning experience and his interest fulfil the students' needs into account.

9. I enjoyed WasUp discussions and learning theory scientist assignment.

10. The course is compressive and related to life

1. The course material is difficult and written in English, there a need for a translated version of the course workbook.

2. The time allocated for studying the course is two short and there may be a need for extra time.

1. Adding Arabic text books and references.

What are your suggestions do you have for improving the course?
2. Develop a field visit to the analysis of learners and be field applied instead of the final test.

3. Teraselated the workbook into Arabic

4. Distributed the course assignment at the beginning of the course.

The study's results show that participants reported high levels of satisfaction with the proposed blended learning experience as a whole and the three component of the blended learning yardstick (Table IV). For the teaching method $(\mathrm{M}=4.62, \mathrm{SD}=.37)$ which expressed a very high level of satisfaction. For the course content $(M=4.50$, $\mathrm{SD}=.41$ ) and indicated a high level of satisfaction, for the course instructor $(\mathrm{M}=4.83, \mathrm{SD}=.28)$ which shows the highest level of satisfaction with blended learning and for the whole course $(\mathrm{M}=4.50, \mathrm{SD}=.31)$ which almost expressed a very high degree of satisfaction.

One sample t-test results (Table V) revealed significance differences in all blended learning components (the teaching method, the course content and the course instructor) as well as the course as a whole i.e. (all values of $\alpha \leq 0.000$ ). Moreover; one way ANOVA test results (Tables, VI, VII \& VIII) also show no significance differences in satisfaction means related to participants` (gender, university degree and learning style).

These results indicated that subjects are benefit from the blended learning experience which enriches their learning and helps them to master the course objective, a fact led to a very high degree of satisfaction with learning the course. The results of this research go with many studies for example; [11], [13] studies that reported a significant positive correlation between teaching quality of teachers and the learning satisfaction of students, between teaching quality of teachers and the academic performance of students, and between the learning satisfaction of students and the academic performance of students; and [18] study which proved student's satisfaction level is related to professor's (or course instructor's) knowledge of materials.

In the light of this study, it is recommended the development of an active learning environment that support student-centered learning activities, and lead to a high degree of satiation with the learning experience. The study recommends adapting the social communications tools available in today communication devices to support students learning and lead to a high degree of satisfaction and motivation for learning. Balance in using innovative learning strategies will help faculties and staff to facilitate their students learning as much as possible to a level that make learning fun and enjoyable by graduate students.

In conclusion, the study, shows that when the distance teaching and training program masters and diploma first-year students are taught by the use of the enhanced blended learning strategy both their achievement and satisfaction with learning are getting improved. Translating the module presentations and the students' workbook units' summaries as well as participating in the WatsUp group discussions are positively affect the learning theory course learning 
outcomes. Both the quantitative learning outcomes represented in subjects achievement and qualitative learning outcomes represented in satisfaction with learning component were enhanced i.e. ( no candidate get less than B+ in the final grade) and no satisfaction of learning yardstick component get less than 3 out of 5 . The study also revealed that there were no significant differences in subjects satisfaction with blended learning related to differences in program of study (diploma, master), subject's gender (male, female), preferred learning styles. Based on the study results the author recommend the use of his enhanced blended learning strategy with Arab Graduate students especially when the program of the study taught in English and when need assessment resulted in language difficulties that may face the students.

\section{ACKNOWLEDGEMENT}

The author would like to thank the distance teaching training master and diploma candidates who participated in this study; thanks also due to the Arabian Gulf University for funding the research and making its publication possible.

\section{REFERENCES}

[1] C. J. Bonk and C. R. Graham, Handbook of Blended Learning: Global Perspectives, Local Designs, San Francisco, CA: Pfeiffer Publishing, 2004, ch. 1, January 2017.

[2] W. S. Chen and A. Y. Yao, "An empirical evaluation of critical factors influencing learner satisfaction in blended learning: A pilot study," Universal Journal of Educational Research, vol. 4, no. 7, pp. 1667-1671, 2016.

[3] M. Mohamad, H. Hussin, and S. Shaharuddin, "Adult learners' perceptions of designed hypermedia in a blended learning course at a public university in Malaysia," Turkish Online Journal of Educational Technology - TOJET, vol. 14, no. 1, pp. 31-38, Jan. 2015.

[4] M. N. Gravani and Y. Karagiorgi, "Underpinning principles of adult learning in face to face (f2f) meetings employed by distance-teaching universities," Journal of Adult and Continuing Education, vol. 20, no. 1, pp. 53-67, Apr 2014.

[5] A. El-Mowafy, M. Kuhn, and T. Snow, "Blended learning in higher education: Current and future challenges in surveying education," Issues in Educational Research, vol. 23, no. 2, pp. 132-15, 2013.

[6] M. V. Pregot, "The case for blended instruction: Is it a proven better way to teach?" Online Submission, pp. 320-324, May 2013.

[7] N. Trukhacheva, S. Tchernysheva, and T. Krjaklina, "The impact of e-learning on medical education in Russia," E-Learning and Digital Media, vol. 8, no. 1, pp. 31-35, 2011.

[8] K. A. Wold, "Blending theories for instructional design: Creating and implementing the structure, environment, experience, and people (SEEP) model," Computer Assisted Language Learning, vol. 24, no. 4, pp. 371-382, 2011.

[9] A. Heinze and C. Procter, "Online communication and information technology education," Journal of Information Technology Education, vol. 5, pp. 235-249, 2006.

[10] M. Stubbs, I. Martin, and L. Endlar, "The structuration of blended learning: Putting holistic design principles into practice," British Journal of Educational Technology, vol. 37, no. 2, pp. 163-175, Mar 2006.

[11] R. Bart, L. Nai, and M. Vicky, "Modeling and managing student satisfaction: Use of student feedback to enhance learning experience," Subscriber Research Series 2015-16, 2017.

[12] Z. B. Babar and R. Kashif, "A study examining the students' satisfaction in higher education," Procedia - Social and Behavioral Sciences, vol. 2, issue 2, pp. 5446-5450, 2010.

[13] K. Wen-Hwa and C. Feng-Ming, "Teaching quality, learning satisfaction, and academic performance among hospitality students in Taiwan," World Journal of Education. vol. 4, no. 5, 2014.

[14] A. Ali and I. Ahmad, "Key factors for determining students' satisfaction in distance learning courses: A study of Allama Iqbal Open University," Contemporary Educational Technology, vol. 2, no. 2, pp. 118-134, 2011
[15] P. L. Hardré and S. M. Hackett, "Understanding the graduate college experience: Perceptual differences by degree type, point-in-program, and disciplinary subgroups," Learning Environments Research, vol. 18, no. 3, pp. 453-468, Oct. 2015.

[16] K. Yu-Chun, B. R. Belland, K. E. E. Schroder, and A. E. Walker, "K-12 teachers' perceptions of and their satisfaction with interaction type in blended learning environments," Distance Education, vol. 35, no. 3, pp. 360-381, 2014.

[17] P. C. Holzweiss, S. A. Joyner, M. B. Fuller, S. Henderson, and R. Young, "Online graduate students' perceptions of best learning experiences," Distance Education, vol. 35, no. 3, pp. 311-323, 2014.

[18] J. Lee, "An exploratory study of effective online learning: Assessing satisfaction levels of graduate students of mathematics education associated with human and design factors of an online course," International Review of Research in Open and Distance Learning, vol. 15, no. 1, pp. 111-132, Feb. 2014.

[19] D. Zeppos. (Oct. 2014). A case study on student satisfaction for graduates of the german language teachers' blended MA program of the Hellenic Open University, classes of 2012 and 2013. Turkish Online Journal of Distance Education. [online]. Available: http:// dergipark.ulakbim.gov.tr/tojde /article/view/5000102149

[20] P. L. McDonald, L. B. Lyons, H. O. Straker, J. S. Barnett, K. S. Schlumpf, L. Cotton, and M. A. Corcoran, "Educational mixology: A pedagogical approach to promoting adoption of technology to support new learning models in health science disciplines," Online Learning, vol. 18, no. 4, Nov. 2014.

[21] A. Francescucci and M. Foster, "The VIRI (virtual, interactive, real-time, instructor-led) classroom: The impact of blended synchronous online courses on student performance, engagement, and satisfaction," Canadian Journal of Higher Education, vol. 43, no. 3, pp. 78-91, 2013

[22] R. Owston, D. York, and S. Murtha, "Student perceptions and achievement in a university blended learning strategic initiative," Internet and Higher Education, vol. 18, pp. 38-46, Jul 2013.

[23] R. Shih, "Effect of using Facebook to assist english for business communication course instruction," Turkish Online Journal of Educational Technology - TOJET, vol. 12, no. 1, pp. 52-59, Jan 2013.

[24] D. U. Bolliger and E. A. Erichsen, "Student satisfaction with blended and online courses based on personality type," Canadian Journal of Learning and Technology, vol. 39, no. 1, pp. 1-23, Nov. 2013.

[25] C. G. Stiles, "The relationship between graduate orientation programs and satisfaction with institutional choice," ProQuest LLC, Ed.D. Dissertation, Johnson \& Wales University, 2012.

[26] E. Martinez-Caro and F. Campuzano-Bolarin, "Factors Affecting students' satisfaction in engineering disciplines: Traditional vs. blended approaches," European Journal of Engineering Education, vol. 36, no. 5, pp. 473-483, 2011.

[27] N. K. Schlossberg, E. B. Waters, and J. Goodman, Counseling Adults in Transition: Linking Practice with Theory, New York: Spring, 1995.

[28] F. Sana, B. Fenesi, and J. A. Kim, "A case study of the introductory psychology blended learning model at McMaster University," Canadian Journal for the Scholarship of Teaching and Learning, vol. 2, no. 1, Article 6, 2011.

[29] A. K. M. Islam, "The determinants of the post-adoption satisfaction of educators with an e-learning system," Journal of Information Systems Education, vol. 22, no. 4, pp. 319-330, Nov.m2011.

[30] E. Martinez-Caro and F. Campuzano-Bolarin, "Factors affecting students' satisfaction in engineering disciplines: Traditional vs. blended approaches," European Journal of Engineering Education, vol. 36, no. 5, pp. 473-483, Oct, 2011.

[31] M. Tam, "Constructivism, Instructional design, and technology: implications for transforming distance learning," Educational Technology \& Society, vol. 3, no. 2, 2000.

[32] P. Honey and A. Mumford, "Manual of learning styles," Maidenhead, Honey, 1992.

[33] National Commission for Academic Accreditation \& AssessmentNCAAA. (2015). Assessing the students' satisfaction with learning instrument. [Online]. Available: http://www.ncaaa.org.sa/en/Pages/default.aspx

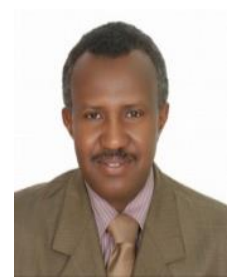

Alajab Mohammed Alajab Ismail is associate professor in instructional technology \& distance learning-Arabian Gulf University, TDTP. Dr. Alajab received the B.Sc. \& education (honors) in physics (1989), the M.Ed. (1994) and the PhD. (2002) in educational technology from Khartoum University in Sudan (2002). In 2012, he received a second PhD in computer science majored in ICT from Rise University, 
Online School of Computer Science (USA).

Dr. Alajab has worked for several higher education institutions and teachers` colleges; Faculty of Education University of Khartoum (1990-2007), Sudan Open University (2005-2007), Albaha Teachers 'College-Saudi Arabia (1998-2002), Faculty of Education-Sultan Quinoas University. He has taught at the under graduate level for over 12 years, and graduate level for over 15 years.
In 2005, he joined the AGU and rising to an associate professor rank by 2011. He wrote the material for the King Hammed (the King of Bahrain) e-learning academic chair. He served as a Vice Dean for Scientific \& Academic Affairs at the Faculty of Education University of Khartoum, director of the DTTP at the AGU, supervised and examined many master's and doctorate thesis in educational technology, distance education. 